\title{
Eesti kõrvallause kõneviiside vastetest ungari keeles
}

\author{
TIINA RÜÜTMAA \\ Tallinna Ülikool, Tartu Ülikool
}

Ülevaade. Uurimuse eesmärk on kaardistada eesti ja ungari kõneviisisüsteemi vastavusi lähtudes kõneviiside funktsioonidest vaadeldavates keeltes. Kõrvallause kõneviiside uurimine annab võimaluse vaadelda ka neid kõneviisivaliku mõjureid, mis ilmnevad ainult kõrvallauses. Näiteks võib kõneviisivalikut mõjutada pealause semantika, samuti teatud sidendid. Relatiivlause predikaadi kõneviis seevastu võib mõjutada pealauset. Kuna lisaks finiitsetele verbivormidele on eesti kõrvallauses levinud ka $d a$ infinitiivis predikaat, on terviklikkuse huvides uurimusse haaratud ka see kõrvallausetüüp. Uurimismaterjalina on kasutatud eestikeelsete ilukirjandustekstide kõrvallauseid ja nende vasteid ungarikeelsetes tõlgetes.

Eesti kõrvallause indikatiivile vastab ülekaalukalt indikatiiv ka ungari keeles, relatiivkõrvallause indikatiivis predikaadile võib ungari keeles siiski vastata ka täiend. Kõige laiem vastete skaala on eesti kõrvallause konditsionaalil: konditsionaal (peamiselt tingimuslikkust väljendavates lausetes), imperatiiv (enamasti lausetes, kus eesti konditsionaal täidab konjunktiivi funktsioone) ja harva ka indikatiiv. $d a$-infinitiivse predikaadiga eesti kõrvallausele vastab ungari keeles enamasti imperatiivis (peamiselt finaallauses), harvem indikatiivis (peamiselt tingimuslauses) või konditsionaalis (peamiselt kõrvutuslauses) predikaadiga kõrvallause. Kvotatiivis ja imperatiivis predikaadiga kõrvallauseid on vaadeldud materjali hulgas järelduste tegemiseks liiga vähe. 
Võtmesõnad: kontrastiivne keeleuurimine; indikatiiv; imperatiiv; konditsionaal; jussiiv; kvotatiiv; konjunktiiv; da-infinitiiv; eesti keel; ungari keel

\section{Sissejuhatus}

Artiklis kõrvutatakse kõneviisisüsteemi eesti ja ungari kõrvallauses, keskendudes eesti kõneviiside funktsioonide väljendusvõimalustele ungari keeles. Eesti ja ungari kõneviisisüsteem on põhiosas sarnane: mõlemas on esindatud indikatiiv, konditsionaal ja imperatiiv. Eesti keeles lisanduvad nimetatutele vahendatud käsku väljendav jussiiv ning kaudsele informatsiooniallikale viitav kvotatiiv. Viimased on siiski küllalt haruldased ja omased vaid teatud tüüpi tekstidele. (vt nt Sepper 2007; Toomet 2000) Lisaks finiitsetele verbivormidele võib eesti kõrvallause öeldiseks olla ka da-infinitiiv (vt EKG II 1993: 244-246). Kuna varasemad ungari keelest lähtuvad uurimused on näidanud, et eesti $d a$-infinitiivis predikaadiga kõrvallause vasteks on ungari keeles enamasti finiitpredikaadiga kõrvallause (nt Rüütmaa 2010: 251-258), on terviklikkuse huvides uurimusse haaratud ka eelnimetatud eesti kõrvallausetüüp.

Vaadeldes eesti ja ungari kõneviiside funktsioone, on pilt märksa keerukam: ka mõlemas keeles esindatud kõneviiside vahel pole üksühest vastavust. Uurimuse eesmärk on kaardistada eesti ja ungari kõneviisisüsteemi vastavused lähtudes kõneviiside funktsioonidest vaadeldavates keeltes. Kõrvallause kõneviisisüsteemi uurides on võimalik pöörata tähelepanu ka neile kõneviisivaliku põhjustele, mis ilmnevad ainult kõrvallauses. Näiteks võib kõneviisivalikut mõjutada pealause semantika: nii eesti konditsionaal kui ungari imperatiiv võivad kõrvallauses täita ka konjunktiivi funktsioone (vt nt Metslang 1999; Prileszky 1974). Samuti võivad kõrvallause kõneviisivalikut tingida teatud sidendid: sidendiga justkui, otsekui, kui, justnagu ja nagu algava võrdleva kõrvallause predikaat on alati konditsionaalis (vt nt Kehayov 2011), st seda tüüpi kõrvallause väljendab alati irreaalset olukorda. Relatiivlause predikaadi kõneviisivalik seevastu võib teatud tingimustel mõjutada pealauset, 
täpsemalt oma peasõna referentsiaalseid omadusi, eelkõige selle spetsiifilisust (Pajusalu \& Pajusalu 2010: 243).

Esmalt antakse võrdlev ülevaade eesti ja ungari kõneviisisüsteemist, seejärel kõrvutatakse kõneviiside funktsioone. Artikli teise peatüki eesti ja ungarikeelsed näited pärinevad viidatud allikatest. Mõned ungarikeelsed näitelaused on koostanud autori ungari kolleeg, eestikeelsed autor ise (võimalusel ungarikeelse näitelause eeskujul). Ungarikeelseid näitelauseid selgitavad glossid ja/või eestikeelne tõlge, viimane juhul, kui eestikeelne vaste struktuurilt ungarikeelsest oluliselt erineb. Artikli neljandas peatükis esitatud näited pärinevad uurimismaterjalist (täpsemalt vt 4.1).

\section{Eesti ja ungari kõneviisidest ja nende peamistest funktsioonidest kõrvallauses}

\subsection{Kõneviisi mõistest ja eesti ning ungari kõneviisisüsteemist}

Kõneviis on verbi morfoloogiline kategooria, mis väljendab modaalsust, näiteks käsku, soovi, faktitiivust, reaalsushinnangut (Thieroff 2010: 2; MG 2000: 106), eesti keeles ka teatelaadi (Metslang \& Sepper 2010: 531-532; EKG II 1993: 34; EKG I 1995: 80). Mõnede autorite arvates tuleks evidentsiaalsust siiski vaadelda eraldi kategooriana (vt nt Thieroff 2010: 3). Antud artiklis lähtutakse EKG eelpool kirjeldatud kõneviisikäsitlusest.

Kõneviisid võib jagada markeerimata ja markeeritud kõneviisideks. Morfoloogiliselt ja modaalselt markeerimata on nii eesti kui ka ungari keeles indikatiiv (EKG I 1995: 80; EKG II 1993: 34, 183; Hegedüs 2005: 258; MG 2000: 107; HL 1997: 95-96), kõik ülejäänud kõneviisid on morfoloogiliselt ja modaalselt markeeritud.

Eesti varasem grammatikatraditsioon nimetas nelja kõneviisi: indikatiiv (kindel), konditsionaal (tingiv), imperatiiv (käskiv) ja kvotatiiv (kaudne); uuemates grammatikates on senine imperatiiv jagatud kaheks: imperatiiviks ja vahendatud käsku väljendavaks jussiiviks (nt EKK 2007; EKG I 1995; EKG II 1993). 
Ungari grammatikad nimetavad traditsiooniliselt kolme kõneviisi: indikatiivi (kijelentő mód), konditsionaali (feltételes mód) ja imperatiivi (felszólitó mód). Viimase funktsioonid on ungari keeles siiski laiemad, haarates ka rahvusvahelises grammatikatraditsioonis jussiivi ja konjunktiivi funktsioonidena käsitletud ülesandeid (vt nt Tóth 2005, 2008; MLN 2001; MG 2000; É. Kiss 1999; Molnár 1994; Pomozi 1991; Pusztay 1991; Pataki 1984; Prileszky 1974). Uuemates grammatikates käsitletakse konjunktiivi juba eraldi keelelise kategooriana (nt MLN 2001; MG 2000; É. Kiss 1999). Viimasel ajal on esitatud seisukohti, et ungari keeles traditsiooniliselt imperatiiviks nimetatud kõneviis ongi pigem konjunktiiv (Groot 2010; Hegedüs 2005).

Eesti kõrvallause kõneviisisüsteem on seega märksa keerulisem kui ungari oma. Samas pole üks ühest vastavust ka mõlemas keeles esindatud kõneviiside vahel. Eesti ja ungari kõneviisisüsteemi erinevused tulenevad osalt grammatikatraditsioonist, osalt aga keeleerinevustest. Eesti uuemas grammatikatraditsioonis määratletakse kõneviisi kui morfoloogilist kategooriat, mis väljendab teate allika hinnangut tegevussituatsiooni suhtele tegelikkusega ja/või kõneleja ja kuulaja osa teatamissituatsioonis ja/või suhtluseesmärki (Rätsep 1971: 58-61). Otsese ja kaudse teatelaadi eristamine on eriomane eesti kõneviisisüsteemi kirjeldusele ja tuleneb eelkõige vajadusest kirjeldada kaudset teatelaadi väljendavat kvotatiivi. Samast kriteeriumist lähtudes on eesti varasema grammatikatraditsiooni imperatiiv jagatud otsest teatelaadi väljendavaks imperatiiviks ja kaudset teatelaadi väljendavaks jussiiviks (Metslang \& Sepper 2010: 531-532). Eesti keeles on seega kõneviisi määratlemise morfoloogilisest printsiibist teatud määral eemaldutud: imperatiivi ja jussiivi kolmanda pöörde vormid kattuvad morfoloogiliselt, nende erinevus on eelkõige funktsionaalne. Kuna ungari kõneviisisüsteemil teatelaadi väljendamise funktsiooni ei ole, ei eristata selles ka imperatiivi ja jussiivi. Viimast võib siiski pidada eelkõige grammatikatraditsioonist tulenevaks erinevuseks. Enam huvi pakuvad otsestest keeleerinevustest tingitud lahknevused eesti ja ungari kõneviisisüsteemis. Üks neist on kvotatiivi puudumine ungari keeles, millest juba eelpool juttu oli, ent 
huvitavat uurimismaterjali pakuvad pigem eesti konditsionaal ja ungari imperatiiv kui tavapärasest laiema funktsiooniskaalaga kõneviisid. Uurimismaterjali iseloomust lähtudes pööratakse antud artiklis põhitähelepanu eesti konditsionaalile ja selle ungari vastetele.

\subsection{Eesti ja ungari kõneviiside peamised funktsioonid}

Indikatiiv on mõlemas keeles nii sisult kui vormilt markeerimata. Kui lauses pole muid modaaltähendustele viitavaid vormivahendeid, näitab indikatiivne verbivorm, et tegemist on reaalse sündmusega. Süntaktiliste, leksikaalsete jms vahenditega võib indikatiivis verbivormiga lausele siiski anda ka muid tähendusi. (EKG I 1995: 80-81; EKG II 1993: 34, 183; Hegedüs 2005: 258; MG 2000: 106-107; HL 1997: 95-96) Indikatiivi funktsioon on edastada kuulajale mõeldud teadet, mille allikas on kõneleja ise või mille allikana ta esineb (EKG I 1995: 80, EKG II 1993: 34; MG 2000: 107, Hegedüs 2005: 258).

Konditsionaal on nii eesti kui ka ungari keeles grammatiliselt ja modaalselt markeeritud. Konditsionaalitunnusega verb viitab sündmuse mittereaalsusele vaatlushetkel, st predikaadiga märgitud tegevus võiks teatud tingimustel toimuda, ent jääb teate allika arvates tõenäoliselt toimumata. (EKG I 1995: 81; EKG II 1993: 34-35; MG 2000: 107; Hegedüs 2005: 259) Siiski ei välistata sündmuse hilisemat teostumist mingi tingimuse korral (EKG II 1993: 35; Hegedüs 2005: 128, 259) (1a, 1b).

(1a) Kui tal raha oleks, reisiks ta palju.

(1b) Ha lenne penze, sokat utazna. kui olema:COND[3SG] raha:POss.3sG, palju:ACC reisima:COND[3SG]

Konditsionaali minevik aga tähendab sisuliselt tegevussituatsiooni eitust: sündmus on jäänud vaatlushetkeks toimumata, ehkki oleks võinud aset leida (EKG II 1993: 35; MG 2000: 107; Hegedüs 2005: 128) (2a, 2b). 
(2a) Kui me varem oleks kohtunud, oleks kõik teisiti läinud.

(2b) Ha korábban találkoztunk volna, minden másképp kui vara:CMPR kohtuma:IMPRF-1PL_COND, kõik teisiti lett volna. olema:IMPRF[3SG]_COND

Konditsionaalis predikaadiga kui/ha-kõrvallause võib väljendada ka soovi (EKG II 1993: 34-35; Hegedüs 2005: 259) (3a, 3b). Soovi tähendus tuleneb siin siiski pealausest, kõrvallauses väljendub eelkõige situatsiooni mittereaalsus.

(3a) Küll oleks tore, kui ilm ilus oleks.

(3b) De jó lenne, ha szép lenne az idő. aga hea olema:COND[3sG], kui ilus olema:COND[3SG] DEF.ART ilm

Konditsionaalivormil võib olla ka pragmaatiline ülesanne: anda soovi, palvet või käsku väljendavale kõrvallausele öeldut pehmendav, viisakam tähendusvarjund (EKG II 1993: 35; Metslang 1999: 122-123; Hegedüs 2005: 265-266) (4a, 4b).

(4a) Oleks kena, kui sa raamatu ära viiks.

(4b) Jó lenne, ha elvinned a könyvet.

hea olema:COND[3SG], kui ära_viima:COND-DET.2SG DEF.ART raamat:ACC

Eesti keeles kasutatakse konditsionaali teatud sidenditega (nt justkui, otsekui, kui, justnagu, nagu) algavas võrdlevas kõrvallauses (Metslang 1999: 116-118, 125; Kehayov 2011) (5a), samuti ettepanekut või arutlust väljendavas võrdlevas kõrvallauses (Metslang 1999: 116-118, 125) (5b). Ungari keeles on alati konditsionaalis sidesõnaga mintha 'justkui, otsekui’ algav kõrvallause (MG 2000: 107; Hegedüs 2005: 193) (5c), samuti soovi väljendav ha-kõrvallause (MG 2000: 107) (3b).

(5a) Korraga lõi ta nägu särama, otsekui oleks päike pilve tagant välja tulnud.

(5b) Mis oleks, kui läheksime kinno?

(5c) Úgy él, mintha király lenne. nii elama:[3sG], justkui kuningas olema:COND[3SG] 'Ta elab nagu kuningas.' 
Eesti konditsionaalil on ka funktsioone, mida enamasti seostatakse konjunktiiviga (vt ka Thieroff 2010: 13-15). Viimast defineeritakse klassikaliselt kui kõneviisi, mis esineb peamiselt kõrvallauses ja mille kasutuse tingib pealause (enamasti selle predikaadi) semantika (nt Marques 2009: 179; Palmer 2001: 3-5; Givón 2001: 312-313). Eesti keeles võivad kõrvallause konditsionaali tingida ka (pea)lause süntaktilised omadused, nt kaasneb konditsionaal sageli teatud soovi/tahet väljendavate verbidega (käskima, soovima, paluma, nõudma, ette panema, lootma, ootama jne (6a, 6b)) ning verbidega näima, paistma ja tunduma (6c) (Metslang 1999: 124). Ungari keeles on nimetatud funktsioon enamasti imperatiivil (vt nt Aradi 2004: 1-4; MLN 2001: 167, MG 2000: 107-108, Pomozi 1991: 4; Pataki 1984: 208, Prileszky 1974: 474, Tompa 1972: 62) (6d, 6e), harva ka konditsionaalil (vt ka Hegedüs 2000: 266; Kálmán 2001: 166) (6f).

(6a) Ta tahtis, et ma teda külastaks.

(6b) Mari nõudis, et Jüri ta rahule jätaks.

(6c) Talle tundus, et ta suudaks enamat.

(6d) Azt kívánom, hogy minden jól sikerüljön.

see:ACC soovima:DET.1SG, et kõik hästi õnnestuma:IMP-3SG 'Soovin, et kõik läheks hästi'.

(6e) Csak azt akarom, hogy hagyjanak békén. ainult see:ACC tahtma:DET.3PL, et jätma:IMP-INDET.PL3 rahu:SUP 'Tahan ainult, et nad mu rahule jätaks mind rahule jäetaks.'

(6f) Nem szeretném, hogy lehámlana a ei tahtma:COND-DET.3SG, et maha_tulema:COND[3SG] DEF.ART bőröm.

nahk:POss.1SG

'Ma ei taha, et mu nahk maha tuleks.'

Eesti keeles on konditsionaalis pealausega erisubjektilise finaallause predikaat (7a), mõnikord ka pealausega samasubjektilise finaallause predikaat, viimase puhul eelistatakse siiski da-infinitiivi (Metslang 1999: 99, 125; EKG II 1993: 310-311). Ungari finaallause predikaat on alati imperatiivis (Prileszky 1974: 474) (7b). 
(7a) Ta surfas internetis, et aeg kiiremini kuluks.

(7b) Az interneten szörfölgetett, hogy gyorsabban DEF.ART internet:SUP surfama:IMPRF.3SG, et kiiremini teljen az idő. kuluma:IMP-3SG DEF.ART aeg

Eesti relatiivlause konditsionaalis predikaat võib viidata oma peasõna mittespetsiifilisusele (Pajusalu \& Pajusalu 2010), nt lause (8a) ehitusmees on kõnelejale veel teadmata; lause ( $8 b$ ) ehitusmees aga aitab juba remonti teha, ent tema asukoht on hetkel teadmata.

(8a) Otsin ehitusmeest, kes aitaks mul remonti teha.

(8b) Otsin ehitusmeest, kes aitab mul remonti teha.

Ungari konditsionaal võib viidata ka kõneleja distantseerumisele öeldust (Farkas 1992) (9a), ent esiplaanil on siiski pigem kõneleja ebakindlus teate suhtes, mitte teatelaadi kaudsus ${ }^{1}$. Eesti keeles on sarnane funktsioon kvotatiivil või $d a$-infinitiivil (EKG II 1993: 36-37) (9b).

(9a) Azt is mondják, hogy Kelemen innét See:ACC ka ütlema:DET.3PL, et Kelemen siit nyerte volna a kedvét. saama:IMPRF.DET.3SG_COND DEF.ART innustus:POSS.3SG-ACC 'Öeldakse ka, et Kelemen olevat just sellest innustust saanud.'

(9b) Räägitakse, et ta olevat/olla just sellest innustust saanud.

Konditsionaali põhifunktsioon on niisiis nii eesti kui ka ungari keeles väljendada tingimuslikkust, ent see võib edasi anda ka soovi/käsku, samuti pehmendada öeldut. Eesti keeles võib kõrvallause konditsionaal kanda ka konjunktiivi ülesandeid, ungari keeles on see funktsioon pigem imperatiivivormil. Eesti keeles on alati konditsionaalis finaallause finiitne predikaat, mis ungari keeles on imperatiivis. Seega on eesti konditsionaalil ungari omast laiem funktsiooniskaala.

Imperatiiv on nii morfoloogiliselt kui ka modaalselt markeeritud. Imperatiivivormi kasutatakse enamasti lausetes, kus kõneleja ootab

1 Csire, Márta, elektronkirjavahetus (28.11.2011). 
kuulajalt mingi olukorra tekitamist, st imperatiivivorm väljendab käsku (EKG I 1995: 82; EKG II 1993: 35; MG 2000: 107).

Eesti kõrvallauses esineb otsest käsku väljendavat imperatiivi teist pööret ning üleskutset väljendavat mitmuse esimest pööret väga harva ja seda enamasti otsekõnesarnastes kõrvallausetes (Metslang 2004: 246; Metslang 2006: 113). Kolmanda pöörde vormid kattuvad jussiviga ja väljendavad kaudset käsku (EKK 2007: 91-96).

Ungari kõrvallause imperatiiv võib samuti väljendada kaudset käsku (10a), ent võib ka tuleneda pealause öeldise semantikast, st olla konjunktiivi funktsioonis (10b). Imperatiivis on ka finaallause predikaat, kõneviisi valiku tingib siin pea- ja kõrvallause loogikaseos (Prileszky 1974: 474) (7b).

(10a) A nővér azt mondta, hogy

DEF.ART õde see:ACC ütlema:IMPRF.DET.3SG, et

menjünk be a beteghez

minema:IMP-1PL PRF DEF.ART haige:ALL

'Õde ütles, et me läheks haige juurde.'

(10b) A nővér megengedte, hogy

DEF.ART õde PRF:lubama: IMPRF.DET.3SG, et

bemenjünk a beteghez

PRF:minema:IMP-1PL DEF.ART haige:ALL

'Õde lubas meil haige juurde minna.'

Eesti imperatiivi ülesanne on niisiis väljendada käsku, ungari kõrvallause imperatiiv täidab lisaks sellele ka konjunktiivi ülesandeid, alati on imperatiivis ungari finaallause predikaat. Viimased kaks funktsiooni on eesti keeles enamasti konditsionaali kanda. Seega on imperatiivil laiem funktsiooniskaala ungari keeles.

Jussiiv esineb ainult eesti keeles ja väljendab peamiselt kaudset tegevusele õhutamist või käsku, mis on suunatud kõnelejalt kõnesituatsioonis mitteosalevale isikule või mis pärineb kõnesituatsioonis mitteosalevalt isikult (EKG I 1995: 83; EKG II 1993: 37) (11a, 11b), ent seda kasutatakse ka möönvas tähenduses (EKK 2007: 91-96) (11c). 
(11a) Ütle neile, et tulgu nad homme ise kohale.

(11b) Jüri räägib ikka, et hoolitsegu ma parem oma enese välimuse eest.

(11c) Olgu te pealegi oodanud siin juba kaks tundi, mina ei saa teid millegagi aidata.

Kvotatiiv esineb samuti vaid eesti keeles ja väljendab vahendatud teadet, st kõneleja edastab kelleltki kolmandalt kuuldud infot ning teate allikas võib käsitada tegevussituatsiooni nii reaalsena kui irreaalsena. Kvotatiiv annab kõneleja suhtumisele ebakindluse varjundi, seda kasutatakse rõhutamaks, et kõneleja ise kahtleb tegevussituatsiooni reaalsuses ega taha vastutust teate õigsuse eest enda peale võtta (EKG I 1995: 82; EKG II 1993: 36) (12). Sarnast tähendust võib mõnikord edasi anda ka ungari konditsionaal (Farkas 1992; vrd (9a)).

(12) Kuulsin, et sa olevat uue töökoha leidnud.

Kvotatiiv on eesti keeles suhteliselt harva esinev kõneviis ja omane pigem ilukirjanduskeelele (vt nt Sepper 2007; Toomet 2000).

\subsection{Eesti ja ungari kõrvallause kõneviiside funktsioonidest}

Eesti ja ungari kõrvallause kõneviiside funktsioone kõrvutades hakkab suurima erinevusena silma pealause semantilisest sisust tulenev kõneviisikasutus. Kui eesti keeles tingib pealause semantika sageli kõrvallause konditsionaalis predikaadi, siis ungari keeles täidab sama funktsiooni enamasti imperatiivivorm. Sama vastavus kehtib ka finaallause öeldise puhul: eesti keeles on see sageli konditsionaalis (pealausega samasubjektilise finaallause öeldis on eesti keeles $d a$-infinitiivis), ungari keeles aga imperatiivis (EKG II 1993: 246, 310; Prileszky 1974: 473-474). Eesti konditsionaali ja ungari imperatiivi teatud funktsioonide sarnasust tõestavad ka varasemad uuringud, kus materjali on analüüsitud ungari keelest lähtuvalt (nt Rüütmaa 2010; Rüütmaa 2007). Eesti ja ungari konditsionaali põhifunktsioon on siiski väljendada tingimuslikkust. Mõlemas keeles võib kõrvallause konditsionaal anda edasi ka käsku, soovi või pehmendada öeldut. Ungari keele grammatikate põhjal võib siiski eeldada, 
et ungari keeles täidab konditsionaal nimetatud funktsioone märksa harvem kui eesti keeles (vt nt Hegedüs 2005: 265-266; MG 2000: 107).

Imperatiivi (ja jussiivi) põhifunktsioon eesti keeles on väljendada käsku. Sama ülesanne on ka ungari imperatiivil, ent lisaks täidab ungari imperatiivivorm ka konjunktiivi funktsioone (vt nt Rüütmaa 2010: 240261).

Kvotatiivi ungari kõneviisisüsteemis pole.

Indikatiivi kui markeerimata kõneviisi funktsioon on mõlemas keeles teate edastamine, ent sellele saab leksikaalsete, morfoloogiliste jms vahendite abil lisada modaalse tähenduse.

Enamik markeeritud kõneviisi valikut tingivaid faktoreid toimib nii pea- kui kõrvallauses. Ainult kõrvallausele avaldab mõju

- pealause semantika: tingib eesti keeles sageli konditsionaali (6a, $6 \mathrm{~b}, 6 \mathrm{c})$, ungari keeles imperatiivivormis predikaadiga kõrvallause (6d);

- $\quad$ pea- ja kõrvallause loogikasuhe: otstarbelause predikaat on eesti keeles sageli konditsionaalis (7a), ungari keeles aga alati imperatiivis (7b);

- teatud sidendid: eesti keeles nõuavad sageli konditsionaali nt sidendid kuigi, ilma et, nagu, justkui, otsekui (5a, 5b), ungari keeles mintha (5c);

- $\quad$ kaudne teatelaad: eesti keeles väljendab kaudset käsku sageli jussiv (11a), kaudset teadet aga kvotatiiv (9b), ungari keeles võib konditsionaal teatud tingimustel väljendada kõneleja distantseerumist öeldust (vt 9a), ent kaudse teatelaadi eristamine ungari keelele siiski omane pole.

Eraldi tuleks vaadelda relatiivlauset, mille kõneviisivalikut pealause ega selle osad ei mõjuta, küll aga võib eesti relatiivlause konditsionaal mõjutada pealause semantikat: sel juhul liigub konditsionaalivormi loodud negatiivne tähenduselement pealausesse, muutes selle ebaspetsiifiliseks (vrd 8a, 8b) (Pajusalu \& Pajusalu 2010) Ungari relatiivlause predikaadi vormil peasõna spetsiifilisusele mõju pole. 


\section{Eesti kõrvallause finiitse predikaadi kõneviiside ja da-infinitiivis predikaadi ungari vastetest}

Indikatiiv väljendab neutraalset kõnelaadi, seega võib eeldada, et eesti indikatiivile vastab enamasti indikatiiv ka ungari keeles. Enam huvi pakub konditsionaal kui kõneviis, mis võib eesti keeles lisaks tavapärasele tingimuslikkuse väljendamisele täita muuhulgas konjunktiivisarnaseid ülesandeid (vt nt Thieroff 2010: 13; Metslang \& Sepper 2010: 539). Ungari keeles peetakse seda üheks imperatiivi funktsioonidest (vt nt MLN 2001: 167; MG 2000: 107-108; É. Kiss 1999: 141-142; Molnár 1994: 41-42; Pomozi 1991: 4; Prileszky 1974: 474; Tompa 1972: 62). Seega võib eeldada, et eesti konditsionaalile vastab ungari keeles küllalt sageli imperatiiv, eelkõige lausetes, kus eesti konditsionaal ei väljenda tingimuslikkust. Kõrvallause imperatiiv (aga ka jussiiv) on eestikeelses tekstis küllalt haruldane ja kuna eesti imperatiivi/jussiivi funktsioone täidab ungari keeles samuti imperatiiv, pole siin ungari vastete seas ilmselt üllatusi. Kvotatiiv ungari keele kõneviisisüsteemis puudub ja on haruldane ka eesti keeles. Arvatavasti vastab eesti kvotatiivile ungari keeles indikatiiv, teatud tüüpi lausetes ka konditsionaal (vt 2.2). Uurimusse on kaasa haaratud ka eesti $d a$-infinitiivis predikaadiga kõrvallause, mille puhul ei saa küll rääkida kõneviisivalikust, ent seda tüüpi lausete hulk eesti kõrvallausete hulgas on küllalt suur, seega on uurimuse terviklikkuse huvides oluline vaadelda ka seda tüüpi eesti kõrvallausete ungari vasteid. $d a$-infinitiivis predikaati esineb eelkõige otstarbe- ja tingimuslausetes, teatud tüüpi relatiivlausetes, vastandavate kõrvutuslausetes ja küsivates kõrvallausetes (EKG II 1993: 244-246, 306-311). Nimetatud lausetüüpides on ungari kõrvallause predikaat sageli imperatiivis, harvem indikatiivis või konditsionaalis (Hegedüs 2005: 259-266; Prileszky 74: 473), seega on tõenäoline, et $d a$-infinitiivis predikaadiga eesti kõrvallausele vastab ungari keeles enamasti imperatiivis, harvem indikatiivis või konditsionaalis predikaadiga kõrvallause.

Eelnevast lähtudes võib eeldada, et eesti kõrvallause modaalse tähendusega kõneviiside ja da-infinitiivi ungari vastete hulgas on kõige 
enam levinud imperatiiv (vt tabel 1) kui ungari keeles väga mitmekesiste funktsioonidega kõneviis.

TABEL 1. Eesti kõrvallause predikaadi kõneviiside ja da-infinitiivis predikaadi eeldatavad vasted ungari keeles

\begin{tabular}{|l|l|}
\hline Eesti keel & Ungari keel \\
\hline indikatiiv & indikatiiv \\
\hline konditsionaal & konditsionaal / imperatiiv \\
\hline imperatiiv / jussiiv & imperatiiv \\
\hline kvotatiiv & konditsionaal / indikatiiv \\
\hline$d a$-infinitiiv & imperatiiv / indikatiiv / konditsionaal \\
\hline
\end{tabular}

\section{Kõneviisid ja da-inifinitiiv eesti kõrvallauses ja nende ungari vasted}

\subsection{Uurimismaterjal}

Uurimismaterjalina on kasutatud eestikeelsetest tekstidest leitud kõrvallauseid ning nende ungari vasteid. Enamiku tekstide puhul on eesti keel originaalkeel ja ungari keel sihtkeel: Sass Henno "Mina olin siin" (tõlge Nóra Rácz "Itt jártam”) ja Andrus Kivirähk "Rehepapp” (tõlge Mónika Segesdi, "Ördöngös idők"). Võrdlusmaterjali hulgas on ka George Orwelli romaani "1984" esimese peatüki eesti- ja ungarikeelsed tõlked (korpus MULTITEXT-East ${ }^{2}$ ). Viimane mitmekesistab materjali ja võimaldab vähendada eesti keele mõju ungari tekstile.

Eestikeelsest tekstist valiti välja (põim)laused ja otsiti välja nende vasted ungarikeelsest tekstist. Kokku leiti 1037 kõrvallauset. Neist 48 lause ungarikeelne tõlge erines originaalist sedavõrd, et need uurimismaterjaliks ei sobinud. Seega on analüüsitud 989 eesti kõrvallauset ja nende ungarikeelseid vasteid, sh 867 indikatiivis, 67 konditsionaalis,

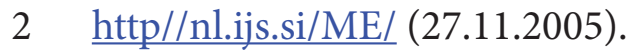


3 kvotatiivis ja 1 imperatiivis predikaadiga kõrvallauset ning $51 \mathrm{da}$-infinitiivis predikaadiga kõrvallauset (vt tabel 2).

\subsection{Eesti kõrvallause kõneviiside ja da-infinitiivse predikaadi ungari vasted uurimismaterjali põhjal}

Eestikeelses tekstis oli kõige enam indikatiivis predikaadiga kõrvallauseid (88\%), sellele järgnevad konditsionaalis (7\%) ja $d a$-infinitiivis predikaadiga kõrvallaused (5\%). Kvotatiivis ja imperatiivis predikaadiga kõrvallauseid ei olnud materjali hulgas piisavalt, et neid analüüsida (vt tabel 2). Seega on modaalsetest kõneviisidest võimalik uurimismaterjali põhjal teha järeldusi vaid konditsionaali kohta.

Eesti indikatiivis predikaadile (867) vastab indikatiiv enamasti ka ungari keeles (820, s.o 95\%). Harva võib eesti kõrvallause indikatiivis predikaadile vastata ka konditsionaal (1\%) või imperatiiv (1\%). Mõnikord vastab eesti põimlausele ungari keeles lihtlause, eesti kõrvallause on sel juhul sisestatud ungari lausesse täiendina (3\%, vt joonis 1).

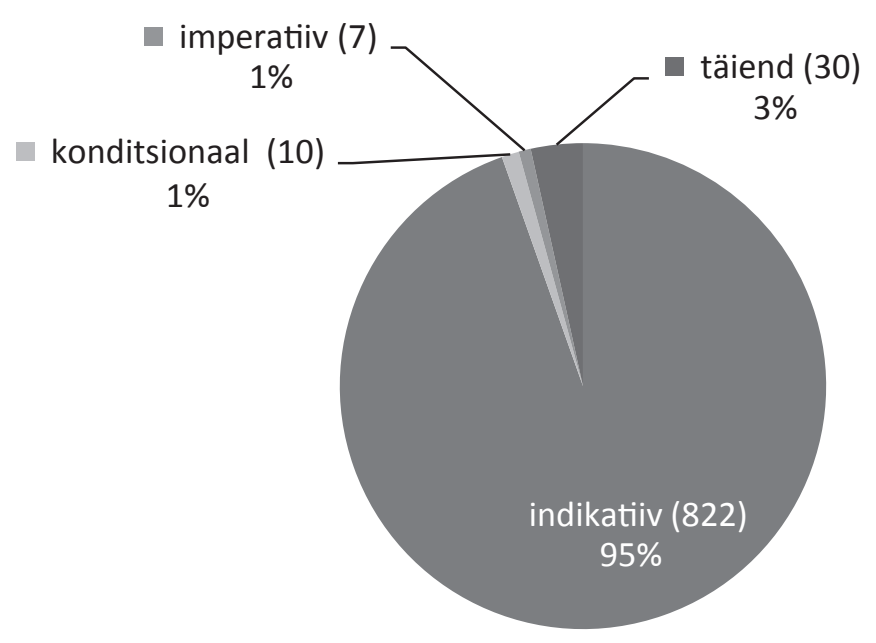

JoonIs 1. Eesti kõrvallause indikatiivi ungari vasted

Eesti kõrvallause konditsionaalis predikaadile (67) vastab kas konditsionaalis (29) või imperatiivis (23), harvem indikatiivis (15) predikaat (vastavalt 43\%, 34\% ja 23\%; vt joonis 2). 


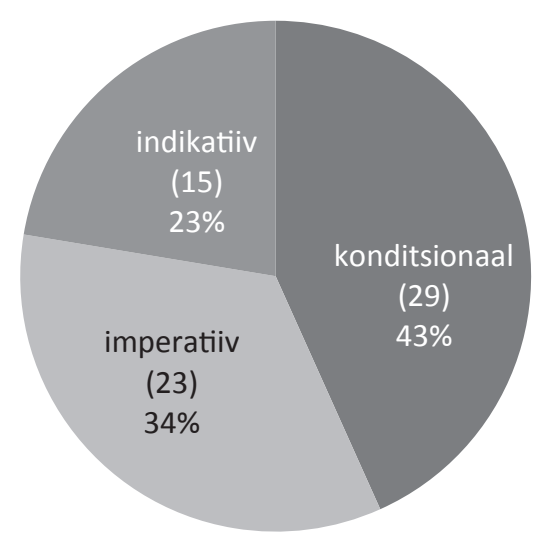

Joonis 2. Eesti kõrvallause konditsionaali ungari vasted

da-infinitiivse predikaadiga kõrvallausele (51) vastab ungari keeles enamasti imperatiivis predikaadiga kõrvallause (33, s.o 65\%), harvem indikatiivis või konditsionaalis predikaadiga kõrvallause (vastavalt 11, s.o $21 \%$ ja 7 , s.o $14 \%$, vt joonis 3).

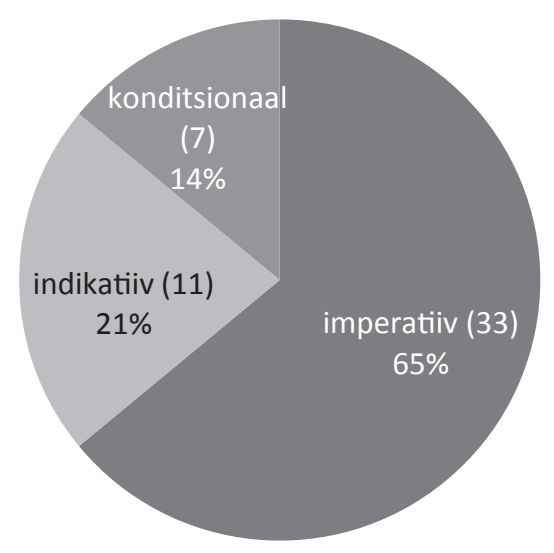

Joonis 3. da-infinitiivis predikaadiga eesti kõrvallause vasted ungari keeles

Kvotatiivis ja imperatiivis predikaadiga kõrvallaused osutusid äärmiselt haruldasteks, materjali põhjal nende kohta järeldusi teha ei saa, ent tekstis esinenud lausete (vastavalt 3 ja 1) vasted vastavad eeldustele (vt tabel 1): kvotatiivis predikaadiga kõrvallausele vastab ungari keeles indikatiivis predikaadiga kõrvallause, imperatiivis predikaadiga kõrvallausele imperatiivis kõrvallause. 
Kokkuvõtlikult kujutab eesti kõrvallause kõneviiside ja $d a$-infinitiivis predikaadiga kõrvallause ungari vastete jaotust tabel 2.

TABEL 2. Eesti kõrvallause predikaadi vorm ja selle vasted ungari keeles

\begin{tabular}{|l|c|l|c|}
\hline \multicolumn{2}{|c|}{ Eesti } & \multicolumn{2}{|c|}{ Ungari } \\
\hline kokku & 989 & kokku & 989 \\
\hline \multirow{4}{*}{ indikatiiv } & \multirow{3}{*}{867} & indikatiiv & 820 \\
\cline { 3 - 4 } & & konditsionaal & 10 \\
\cline { 3 - 4 } & & imperatiiv & 7 \\
\cline { 3 - 4 } & & täiend & 30 \\
\hline \multirow{4}{*}{ konditsionaal } & \multirow{3}{*}{67} & konditsionaal & 29 \\
\cline { 3 - 4 } & & imperatiiv & 23 \\
\cline { 3 - 4 } & \multirow{2}{*}{ kvotatiiv } & indikatiiv & 15 \\
\hline imperatiiv & \multirow{3}{*}{ da-infinitiiv } & indikatiiv & 3 \\
\hline \multirow{3}{*}{51} & imperatiiv & 1 \\
\cline { 3 - 4 } & & imperatiiv & 33 \\
\cline { 3 - 4 } & & indikatiiv & 11 \\
\cline { 3 - 4 } & & konditsional & 7 \\
\hline
\end{tabular}

\subsection{Eesti kõrvallause indikatiivi vasted ungari keeles}

Eesti indikatiivis predikaadile (867 lauset) vastab indikatiiv enamasti ka ungari keeles (820, vt tabel 2). Kuna indikatiiv on nii eesti kui ka ungari keeles morfoloogiliselt ja modaalselt markeerimata kõneviis, mille funktsioon on teate edastamine, võib seda pidada igati ootuspäraseks.

(13a) Muidugi oli täiesti võimatu öelda, kas sind parajasti valvatakse või mitte.

(13b) Azt persze nem lehetett tudni, hogy egy adott pillanatban éppen megfigyelik-e az embert.

(14a) Nüüd te märkate, et ma ei kirjuta enam.

(14b) Most észreveszitek, hogy nem írok. 
(15a) Ma olen näinud küll, mis te seal mõisa sahvris teete.

(15b) Láttam én, miket müveltek az uradalom éléskamrájában.

Mõnel üksikul juhul vastab eesti indikatiivile siiski konditsionaal või imperatiiv, vastavalt 10 ja 7 lauset (vt tabel 2).

Eesti indikatiivile vastab ungari keeles konditsionaal enamasti irreaalset olukorda kirjeldavates lausetes (16-18). Konditsionaali kasutuse ungari keeles võib tingida muuhulgas pealause eituselement, nt lauses 16 (vt ka Kálmán 2001: 166). Samuti võib ungari konditsionaal vastata eesti indikatiivile lausetes, mille pealause väljendab arvamist (17) ning kujuteldavat olukorda väljendavas kõrvallauses (18). Samu lauseid võiks vormistada konditsionaaliga ka eesti keeles.

(16a) --- kuni politsei viis ta minema ma ei usu, et temaga midagi tehakse

(16b) --- míg a rendőrség el nem távolította nem hiszem, hogy baja esett volna ---

(17a) Mis sa arvad, et ma muu pärast sind üles korjasin?

(17b) Mit gondolsz, mi másért szedtelek volna föl?

(18a) Ta vihkas teda sellepärast, --- , et ta tahtis temaga voodisse minna, ---

(18b) Gyülölte, --- ; mert szeretett volna lefeküdni vele, ---

Eesti indikatiivi vastena esinev ungari imperatiiv on enamasti konjunktiivi funktsioonis (19-21), kõneviisivaliku tingib niisiis pealause semantika või struktuur. Alltoodud kõrvallaused väljendavad kujuteldavat olukorda $(19,20)$ või olukorra tingitust pealausega kirjeldatust $(21)$. Ka eesti keeles pole alltoodud kõrvallausetes indikatiiv ainuvõimalik: predikaat võiks olla ka (konjunktiivi funktsioonis) konditsionaalis $(20,21)$ või $d a$-infinitiivis (19). Indikatiiv viitab olukorra realiseerumise suurele tõenäosusele $(19,20)$ või juba realiseerunud situatsioonile (21).

(19a) Ja kui seekord juba poiss ise trepist alla ust avama läks, ei teadnud ta veel isegi, mida ta ütleb.

(19b) És amikor a fiú maga ment le ajtót nyitni, nem tudta még, mit mondjon. 
(20a) Nad ajasid veel veidi juttu ja ootasid, millal haigus tagasi tõmbub.

(20b) Még beszélgettek egy kicsit, várták, hogy visszahúzódjon a kórság.

(21a) --- kuid siiski piisavalt kõvasti, et Säde tigedalt poisil vait olla käskis.

(21b) --- ám mégis elég hangosan ahhoz, hogy Szikra dühösen csendre intse.

Relatiivlauseid oli eesti indikatiivis kõrvallausete (867) hulgas 267. Enamikul juhtudel (236 lauses) vastas indikatiivis predikaadiga eesti relatiivlausele indikatiivis predikaadiga kõrvallause ka ungari keeles (22-23). Märkimisväärse rühma moodustavad ka laused, milles eesti indikatiivis predikaadiga relatiivlause on ungari keeles sisestatud iseseisvasse lausesse täiendina (23 lauset), s.o ligi 11\% eesti indikatiivis predikaadiga relatiivlause ungari vastetest (24-26). Viimaste struktuuri selgitamiseks on järgnevates näitelausetes lisatud ungarikeelsetele lausetele sõnasõnaline tõlge.

(22a) Need mõtted, mis vangistuses tulevad, on alati kõige kasutumad, ---

(22b) A letartóztatás idején megfogalmazódó gondolatok a leghasznavehetetlenebbek, --'vangistuse ajal tulevad/sõnastuvad mõtted (on) kõige kasutumad'

(23a) Eemale rajoonist, kus oma esimesed viisteist aastat elas ka tüüp, kes seda lugu praegu jutustab.

(23b) Messzire a lakóteleptől, ahol e történet mesélője életének első tizenöt évét töltötte.

'eemale rajoonist, kus selle loo jutustaja oma elu esimesed viisteist aastat veetis'

(24a) Selle ühes otsas oli seinale kinnitatud värviline plakat, mis oli siseruumi kohta liiga suur.

(24b) Egyik végén egy --- épületen belüli elhelyezés céljára túlságosan is nagyméretü --- plakát volt a falra szegezve.

ühes otsas ehitise sees paiknemiseks liigagi suur plakat oli seina naelutatud' 
(25a) Kleit, millest ta rääkis, oli vana parunessi eelmine surikleit.

(25b) A szóban forgó darab az idős bárónő előző halotti ruhája volt.

'kõnealune ese vana parunessi eelmine surikleit oli'

(26a) Igaüks ratsutas just selle looma seljas, kes oli talle peiedeks tapetud.

(26b) Mindegyik a halotti torára levágott állat hátán ült.

'igaüks oma peiedeks tapetud looma seljas istus'

Harva on eesti indikatiivis relatiivlause vasteks ungari keeles konditsionaalis predikaadiga kõrvallause (27a, 27b). Tegemist on lausetega, kus konditsionaali võinuks kasutada ka eesti keeles, viidatud on realiseerumata jäänud olukorrale.

(27a) Mitte igal hingel polnud taret, kus teda oodati ega kuumaks köetud sauna, kuhu oli valmis pandud tubli toit ning parimad kasevihad.

(27b) Nem minden léleknek volt tanyája, ahol várták volna a háziak jól befütött szaunával, szaunavirgáccsal, finom ételekkel.

\subsection{Eesti kõrvallause konditsionaali vasted ungari keeles}

Eesti kõrvallause konditsionaalis predikaadile (67 lauset) vastab ungari keeles kas konditsionaalis või imperatiivis predikaat (vastavalt 29 ja 23; vt tabel 2).

Konditsionaal vastab eesti konditsionaalile kõige sagedamini tingimuslauses (28-29), tihti ka sihitis- (30-31), harva aluslauses (32). Viimastes tuleneb konditsionaalivorm eesti keeles pealause öeldise semantikast. Ungari keeles võib neis lausetes ebakindlust mõnikord rõhutada (29) või anda edasi eesti konditsionaalis modaalverbi võima tähendust (31) ka potensiaaliliide -hat/-het (vt ka 38). Seda tüüpi lausetes saab ungari konditsionaali enamasti asendada imperatiiviga (vt ka Hegedüs 2005: 193).

(28a) See oleks olnud äärmiselt ohtlik isegi siis, kui ta oleks teadnud, kuidas seda teha.

(28b) Elképzelhetetlenül veszedelmes dolog lett volna még akkor is, ha tudta volna, hogyan lásson neki a dolognak. 
(29a) --- nad varastaksid sipelgate pesast okkad ka ära, kui saaks!

(29b) --- a hangyabolyból is ellopnák a tüleveleket, ha tehetnék.

(30a) Mõtle, kui oleks kogu aeg soe ja päike paistaks.

(30b) Gondolj bele, ha mindig meleg lenne és sütne a nap ---

(31a) Tead, ma mõtlesin, et me võiks ära sõita, ---

(31b) Tudod, arra gondoltam, hogy elutazhatnánk, ---

(32a) No vat nüüd oleks paras, kui sa selle hea asjaga hauda läheksid!

(32b) Jobb is lenne, ha az a finomság sírba vinne.

Imperatiiv vastab eesti konditsionaalile kõige sagedamini põhjus(33-34) ja sihitislauses (36-37), st lausetes, mis väljendavad veel realiseerumata irreaalset situatsiooni (vt ka Hegedüs 2005: 193). Eesti konditsionaal ei väljenda siin tingimuslikkust, predikaadi vormi tingib pealause predikaadi semantika või lause struktuur. Eesti konditsionaali võib pidada pigem lähedaseks konjunktiivile (vt ka Metslang \& Sepper 2010; Metslang 1999). Kuna ungari keeles täidab konjunktiivi funktsioone enamasti imperatiiv, on vasted igati ootuspärased.

(33a) Alati tuli valvel olla, et keegi su vara minema ei tassiks, ---

(33b) Mindig résen kellett lenni, hogy senki se dézsmálhassa meg az ember javait.

(34a) Seda on vaja, et ma saaks alustada.

(34b) Ami kell ahhoz, hogy el tudjam kezdeni.

(35a) --- ma tahan, et te teaks, kes ma tegelikult olen.

(35b) --- azt akarom, hogy tudjátok, ki is vagyok én valójában.

(36a) Mõssa ütles, et korjaks Rassi kaasa, ---

(36b) Mõssa azt mondta, szedjük össze Rasst is, ---

(37a) Ole ikka mõistlik mees, Sander, ja ütle, mis ma peaks sulasega tegema?

(37b) Légy megértő, Sander, és mondd meg, mit csináljak a béresemmel?

Eesti konditsionaali modaalsust annab mõnikord ungari kõrvallauses edasi (või rõhutab seda) võimalikkust väljendav liide -hat/-het (vt ka 
Hegedűs 2005: 193). Sel juhul on predikaat sageli konditsionaalis (29) või imperatiivis (33). Enamasti on ungari potensiaaliliide aga pigem eesti modaalverbi võima vasteks $(31,38)$.

(38a) --- , sugugi pelgamata, et isa tõele jälile võiks saada ja välja nuuskida, kuhu kallis hõbeehe tegelikult pandi.

(38b) --- , cseppet sem tartva attól, hogy apja rájöhet az igazságra, kiszimatolja, hová is vándorolt a drága ékszer.

Mõnel juhul pole ungari keeles eesti konditsionaaliga väljendatud tingimuslikkuse väljendamist vajalikuks peetud. Näiteks lausetüübis, kus eitav tingimuslause väljendab reaalset sündmust, mis on pealausega kirjeldatud sündmust muutnud. Ehkki lause (39a) kui-kõrvallause on eitav, väljendab see toimunud sündmust - ilves läks üle tee -; mille toimumata jäämine tinginuks pealauses kirjeldatud sündmuste teistsuguse arengu. Ungari keeles kasutatakse seda tüüpi tingimuslauses sageli indikatiivi, ent võimalik oleks ka konditsionaal ${ }^{3}$.

(39a) ---, mis ta teinud oleks ja kui palju Jaani verd valanud, kui mitte korraga poleks üle tee läinud ilves ---

(39b) ---, mit tett volna, mennyi vérét ontotta volna a béresnek, ha egyszer csak át nem megy előttük az úton egy hiúz ---

Erinevalt indikatiivis predikaadiga relatiivlausest ei vasta eesti konditsionaalis predikaadiga kõrvallausele kordagi täiend. Kõige sagedasem ungari vaste selles lausetüübis on konditsionaal (40-43). Konditsionaali modaalsust võib ungari keeles lisaks rõhutada potensiaaliliide -hat/-het, lisades sellele võimalikkuse tähenduse $(42,43)$.

(40a) --- ja jalas mingid kuradi velvetpüksid, mille kandmise ma oleks tal ära keelanud.

(40b) --- és valami kibaszott bársonynadrágot viselt, amit én bizony betiltottam volna.

3 Csire, Márta, elektronkirjavahetus (28.11.2011). 
(41a) Ei möödunud ainsatki päeva, kus Mõttepolitsei poleks paljastanud spioone ja sabotööre, kes tegutsesid tema juhendusel.

(41b) Nem múlt el egyetlen nap sem, hogy a Gondolatrendőrség ne leplezett volna le az ő irányításával működő kémeket és szabotőröket.

(42a) Ta püüdis leida mõnd lapsepõlvemälestust, mis ütleks, kas London on alati selline olnud.

(42b) Megpróbált felidézni magában valami gyermekkori emléket, amely megmondhatná neki, vajon mindig ilyen volt-e London, mint most.

(43a) Tüdrukut kuulates mõtles ta kiiresti läbi kõikvõimalikke olukordi, mis natukenegi rahaliselt aitaksid.

(43b) Amíg a lányt hallgatta, gyorsan átgondolta az összes lehetőséget, ami egy kicsit is segíthetne anyagilag.

Harva vastas eesti konditsionaalis predikaadiga relatiivkõrvallausele indikatiiv (44a, 44b). Eesti keel käsitleb alltoodud situatsiooni irreaalsena, ungari keeles aga kõrvallause seisukohalt reaalsena (hüpoteetiline elukas, kel pole minu üle võimu), st eesti keel rõhutab pigem situatsiooni, ungari keel aga peasõna irreaalsust (vrd näitelausega (39), kus kõneviisivalik samuti eesti keeles pigem kogu situatsioonist, ungari keeles aga kõrvallausest lähtub).

(44a) --- mul oli tarvis ühte sellist pruugitud elukat, kellel poleks minu üle mingit voli.

(44b) --- pontosan egy ilyen használt jószágra volt szükségem, akinek nincs hatalma fölöttem.

\subsection{Eesti da-infinitiivis predikaadiga kõrvallause vasted ungari keeles}

Eesti $d a$-infinitiivse predikaadiga kõrvallausele vastab ungari keeles enamasti imperatiivis predikaadiga kõrvallause (33 lauset), harvem indikatiivis või konditsionaalis predikaadiga kõrvallause (vastavalt 11 ja 7 lauset, vt tabel 2)

Vaadeldud materjali hulgas oli kõige enam $d a$-infinitiivis predikaadiga finaallauseid (25 lauset). Kuna ungari keeles on finaallause predi- 
kaat alati imperatiivivormis (konjunktiivis) on tulemus ootuspärane (45-47).

(45a) Ümber tema tunkede oli mitmekordselt keeratud kitsas helepunane vöö, ---, küllalt tihedalt, et esile tõsta tema puusade vormikust.

(45b) Néha keskeny piros övet viselt az overallján a dereka köré tekerve, elég szorosan, hogy kiemelje formás csípöjét.

(46a) Rass nõjatus taha vaatamata pingi seljatoele, et teda paremini kuulda.

(46b) Rass nem fordult meg, de hátradőlt, hogy jobban hallja a lányt.

(47a) Tahtsin jalaga vastu maad lüüa, et kurivaim kinni pidada, ---

(47b) Akartam én toppantani, hogy megállítsam a pokolfajzatját, ---

Ka da-infinitiivis predikaadiga sihitis- (48-49) ja rektisoonimääruskõrvallausele (50) võib ungari keeles vastata imperatiivse predikaadiga kõrvallause (vt ka Hegedüs 2005: 259-266; Prileszky 74: 473). Ungari imperatiivivorm tuleneb vaadeldud lausetes pealause semantikast, st on konjunktiivi funktsioonis.

(48a) See oleks olnud äärmiselt ohtlik isegi siis, kui ta oleks teadnud, kuidas seda teha.

(48b) Elképzelhetetlenül veszedelmes dolog lett volna még akkor is, ha tudta volna, hogyan lásson neki a dolognak.

(49a) Rass mõtles, mida järgmiseks öelda.

(49b) Rass azon gondolkozott, erre mit mondjon.

(50a) Liina pidas aru, mida isale uue kleidi kohta rääkida.

(50b) Liina azon törte a fejét, mit mondjon apjának az új ruháról.

Eesti kõrvutuslause $d a$-infinitiivis predikaadile seevastu vastab ungari keeles enamasti konditsionaalis predikaadiga kõrvallause (51-53), harva $\mathrm{ka}$ imperatiivis predikaadiga kõrvallause (54). Vaadeldavates lausetes pole kõrvallausega kirjeldatud situatsioon veel realiseerunud, st predikaat väljendab irreaalset olukorda, mida ungari keeles võib anda edasi nii konditsionaal kui ka konjunktiivi funktsioonis imperatiivivorm (Hegedüs 2005: 193). 
(51a) ---, et see ilus kreemjas paber on seda väärt, et sinna kirjutataks ehtsa sulega, selle asemel et kriipida seda tindipliiatsiga.

(51b) ---, a gyönyörű krémszínü papír megérdemli, hogy valódi tollal írjanak rá, ahelyett, hogy tintaceruzával kaparnának rajta.

(52a) Lapsed, kes mängisid teineteise närvidega, selle asemel et mängida kodu.

(52b) Gyerekek, akik mások idegeit tépték, ahelyett, hogy otthont játszottak volna.

(53a) Selle asemel, et Rassile kallale tormata, lõi ta maaslamajale jalaga selga ---

(53b) Ahelyett, hogy Rassra támadt volna, hátba rúgta a földön fekvőt, ---

(54a) Selle asemel, et muuta neile talutavaks kõike muud, mis on veel minu võimuses.

(54b) Ahelyett, hogy elviselhetővé tegyek számukra minden mást, amin még hatalmamban áll változtatni.

Eesti $d a$-infinitiivis predikaadiga tingimuslause väljendab alati reaalset võimalust (EKG II 1993: 308), ootuspäraselt vastab neile ungari keeles indikatiivis predikaadiga kõrvallause: ungari keeles kasutatakse reaalselt teostuda võivat olukorda väljendavas tingimuslauses (kui juhtub üks asi, siis juhtub ka teine) indikatiivi (Hegedűs 2005: 128).

(55a) Kui tollida autosid ilma esiklaasi, kapoti, tulede ja usteta, maksad kordades vähem.

(55b) Ha első szélvédő, motorháztető, lámpa és ajtók nélkül vámoltatod el a kocsit, sokkal kevesebbet kell fizetned érte.

(56a) Kui juba saata kratt mõisa vedama, siis las toob tarvilikke asju ---

(56b) Ha már az uradalomba küldöd a krattod, inkább hasznos dolgokat hozzon ---

(57a) Kui vana kuu ajal kolm korda puu tüve peale koputada, kuivab puu ära!

(57b) Ha teliholdkor háromszor megkopogtatod a fa törzsét, elszárad! 


\section{Kokkuvõte}

Eesti ja ungari kõrvallause kõneviisisüsteem on põhiosas sarnane: mõlemas on esindatud indikatiiv, konditsionaal ja imperatiiv. Eesti keeles lisanduvad nimetatutele vahendatud käsku väljendav jussiiv ning kaudsele informatsiooniallikale viitav kvotatiiv; teatud tüüpi kõrvallausete öeldiseks võib eesti keeles olla ka $d a$-infinitiiv.

Eesti ja ungari kõneviisisüsteemi süstematiseerimise erinevused tulenevad osalt grammatikatraditsiooni (jussiivi puudumine ungari keeles), osalt keeleerinevustest (eesti konditsionaalil ja ungari imperatiivil on tavapärasest enam funktsioone, ungari keeles puudub kvotatiiv).

Uurimismaterjalist selgus, et eesti indikatiivis predikaadile vastab enamasti indikatiiv ka ungari keeles (95\%); eesti indikatiivis predikaadiga relatiivkõrvallause võib ka olla sisestatud ungari lausesse täiendina (s.o 3\% kõigist eesti indikatiivis kõrvallausetest ja ligi 11\% eesti indikatiivis relatiivlausest).

Eesti kõrvallause konditsionaalis predikaadile vastab kas konditsionaalis (43\%) või imperatiivis (34\%), harvem indikatiivis (23\%) predikaat.

Konditsionaal vastab eesti konditsionaalile kõige sagedamini tingimus- ja sihitislauses, sh osas lausetest, kus eesti konditsionaalil on konjunktiivisarnased funktsioonid. Viimases lausetüübis võib ungari konditsionaali enamasti asendada imperatiiviga. Kuna ungari keeles täidab konjunktiivi funktsioone valdavalt imperatiiv, on see igati ootuspärane. Imperatiiv vastabki eesti konditsionaalile kõige sagedamini põhjus- ja sihitislauses, kus eesti konditsionaalil võivad olla konjunktiivi funktsioonid.

Erinevalt indikatiivis predikaadiga relatiivlausest ei vasta konditsionaalis predikaadiga relatiivlausele kordagi täiend. Kõige sagedamini vastab konditsionaalis predikaadiga relatiivlausele ungari keeles konditsionaalis, harvem indikatiivis või imperatiivis predikaadiga kõrvallause.

$d a$-infinitiivse predikaadiga eesti kõrvallausele vastab ungari keeles enamasti imperatiivis (65\%), harvem indikatiivis (21\%) või konditsionaalis (14\%) predikaadiga kõrvallause. 
$d a$-infinitiivis predikaadiga finaallausele vastab ungari keeles alati imperatiivse predikaadiga kõrvallause. Imperatiivse predikaadiga ungari kõrvallause võib vastata ka $d a$-infinitiivis predikaadiga sihitis- ja rektsioonikõrvallausele. Seevastu $d a$-infinitiivis predikaadiga tingimuslausele, mis väljendab eesti keeles alati reaalset võimalust, vastab ungari keeles indikatiivis predikaadiga kõrvallause; indikatiivis predikaadiga ungari kõrvallause vastab $d a$-infinitiivis predikaadiga eesti kõrvallausele ka üksikutes alus-, sihitis-, tingimus- ja relatiivlausetes.

Kvotatiivis ja imperatiivis predikaadiga kõrvallauseid on vaadeldud materjali hulgas järelduste tegemiseks liiga vähe.

Konditsionaalis ja $d a$-infinitiivis predikaadiga eesti kõrvallausete ungari vastete seas on seega kõige sagedasem imperatiiv (56 lauset), märksa harvem esineb konditsionaali (36 lauset) ja indikatiivi (26 lauset). Tulemus on igati ootuspärane: ungari kõrvallauses täidab imperatiivivorm konjunktiivi funktsiooni, mida omistatakse ka eesti konditsionaalile. Eesti da-infinitiivis predikaadiga kõrvallause aga on levinud lausetüüpides, mille predikaat on ungari keeles enamasti imperatiivivormis (nt otstarbelause).

Kõneviisidest on kõige kirevam vasteskaala eesti konditsionaalil, ent vastete hulgas on kõige levinum siiski ungari konditsionaal. Tulemus on ootuspärane, kuna eesti ja ungari konditsionaali põhifunktsioon on tingimuslikkuse väljendamine. Eesti konditsionaali tavapärasest laiemad funktsioonid avalduvad kõige selgemini lausetes, kus kõneviisivaliku tingib eesti keeles (pea)lause predikaadi semantika. Ka selles lausetüübis esineb ungari vastete seas konditsionaali, mis on ungari keeles teatud lausetüüpides imperatiivi paralleelvõimalus, ent sagedasim vaste on siiski imperatiiv. 


\section{Tänusõnad}

Artikli valmimist on toetanud Alfred Kordelini sihtasutuse Eesti allfond.

\section{Lühendid}

$\begin{array}{ll}\text { ACC } & \text { akusatiiv } \\ \text { ALL } & \text { allatiiv } \\ \text { ART } & \text { artikkel } \\ \text { COND } & \text { konditsionaal } \\ \text { CPR } & \text { komparatiiv } \\ \text { DEF } & \text { definiitne } \\ \text { DET } & \text { determineeritud } \\ \text { IMP } & \text { imperatiiv } \\ \text { IMPRF } & \text { imperfekt } \\ \text { INDET } & \text { indetermineeritud } \\ \text { PL } & \text { plural } \\ \text { POSS } & \text { possessiivsufiks } \\ \text { PRF } & \text { prefiks } \\ \text { SG } & \text { singular } \\ \text { SUP } & \text { superessiiv }\end{array}$

\section{Kirjandus}

Aradi, András 2004. A magyar kötőmódhasználat kérdéséhez, Előadás a VII. Nemzetközi Magyar Nyelvtudományi Kongresszuson. http://www.nytud. hu/NMNyK/eloadas/aradia.rtf (22.04.2010).

Erelt, Mati, Helle Metslang 2004. Grammar and pragmatics: Changes in the paradigm of the Estonian imperative. - Linguistica Uralica XL (3), 161-178.

É. Kiss, Katalin 1999. Mondattan. - Katalin É. Kiss, Ferenc Kiefer, Péter Siptár (Szerk.). Új magyar nyelvtan. Budapest: Osiris Kiadó, 15-184.

EKK 2007 = Erelt, Mati, Tiiu Erelt, Kristiina Ross 2007. Eesti keele käsiraamat. Tallinn: Eesti Keele Sihtasutus.

EKG I 1995 = Erelt, Mati, Reet Kasik, Helle Metslang, Henno Rajandi, Kristiina Ross, Henn Saari, Kaja Tael, Silvi Vare 1995. Eesti keele grammatika I. Morfoloogia. Sõnamoodustus. Tallinn: Eesti TA KKI.

EKG II 1993 = Erelt, Mati, Reet Kasik, Helle Metslang, Henno Rajandi, Kristiina Ross, Henn Saari, Kaja Tael, Silvi Vare 1993. Eesti keele grammatika II. Süntaks. Tallinn: Eesti TA KKI. 
Farkas, Donka F. 1992. Mood choice in complement clauses. - István Kenesei (Szerk.). Approaches to Hungarian. Vol. IV. The Structure of Hungarian. Szeged: JATE, 207-225.

Givón, Talmy 2001. Syntax I. Amsterdam: Benjamins.

Groot, Casper de 2010. Mood in Hungarian. - Björn Rothstein, Rolf Thieroff (Eds.). Mood in the Languages of Europe. Studies in Language Companion Series 120. Amsterdam: Benjamins, 551-568.

Hegedüs, Rita 2005. Magyar nyelvtan. Formák, funkciók, összefüggések. Budapest: Tinta Könyvkiadó.

Hegedüs, Rita 1990. A konjunktivusz problémája a németben és a magyarban. Orsolya Egyed, Béla Ciay, Orsolya B. Nádor (Szerk.). Hagyományok és módszerek. Az I. Nemzetközi Hungarológia-Okatatási Konferencia előadásai II. Budapest: Nemzetközi Hungarológiai Központ, 63-74.

Kálmán, László 2001. Magyar leíró nyelvtan. Mondattan I. Szerk. Kálmán László. Segédkönyvcek a nyelvészet tanulmányozásához VI. Budapest: Tinta Könyvkiadó.

Kehayov, Petar 2011. Semantic functions of complementizers in Finnic (Estonian, Finnish, Karelian). - LANCHART workshop on Semantic Functions of Complementizers in European Languages (28.-29.10.2011, Copenhagen). http://dgcss.hum.ku.dk/arrangementer/ExAPP/programme - semantic functions/Presentation Kehayov.pdf/ (2.08.2012).

Keresztes, László 1997. Praktiline ungari keele grammatika. Hungarolingua. Debrecen: Debreceni Nyári Egyetem.

Marques, Rui 2009. On the selection of mood in complement clauses. - Lotte Hogeweg, Helen de Hoop, Andrej Malchukov (Eds.). Cross-Linguistic Semantics of Tense, Aspect and Modality. Linguistics Today 148. Amsterdam: John Benjamins, 179-204.

Metslang, Helle 1999. Is the Estonian and Finnish conditional actually a conditional? - Mati Erelt (Ed.). Estonian Typological Studies III. Publications of the Department of Estonian of the University of Tartu 11. Tartu: Tartu University, 97-128.

Metslang, Helle 2004. Imperative and related matters in everyday Estonian. - Linguistica Uralica XL (4), 243-256.

Metslang, Helle 2006. Imperatiivist ja direktiivsusest ning nende dünaamikast eesti ja soome keeles. - Helle Metslang, Siiri Soidro (Toim). Lähivertailuja 16. Tallinna Ülikooli eesti filoloogia osakonna toimetised 7. Tallinn: TLÜ Kirjastus, 111-134. 
Metslang, Helle, Maria-Maren Sepper 2009. Mood in Estonian. - Björn Rothstein, Rolf Thieroff (Eds.). Mood in the Languages of Europe. Studies in Language Companion Series 120. Amsterdam: John Benjamins, 528-549

MG 2000 = Balogh, Judit, Lea Haader, Borbála Keszler, Nóra Kugler, Krisztina Laczkó, Klára Lengyel 2000. Magyar grammatika. Budapest: Nemzeti Tankönyvkiadó.

MLN 2001= Bárneti, Zoltán, Kálmán Dudás, Beáta Gyuris, László Kálmán, Attila Novák, Viktor Trón 2001. Magyar leíró nyelvtan. Mondattan I. - Segédkönyvek a nyelvészet tanulmányozásához VI. Budapest: Tinta Könyvkiadó. MMNyR 1962 = Deme, László, Vilmos Farkas, Antónia S. Hámori, Imre Samu, Sándor B. Károly, Éva Lőrinczy, Ilona H. Molnár, Éva Ruzsiczky, György Szépe, Mihály Temesi, József Tompa, 1962. A mai magyar nyelv rendszere. II. Budapest: Akadémiai Kiadó.

Molnár, Ilona 1994. Az alárendelt mondatbeli felszólító módról: a magyar kötőmód kérdéséhez. -Marianne Bakró-Nagy (Szerk.). Nyelvtudományi közlemények 94. Budapest: Magyar Tudományos Akadémia Nyelvtudományi Intézete, 5-43.

Pajusalu, Renate, Karl Pajusalu 2004. The conditional in everyday Estonian: It's forms and functions. - Linguistica Uralica XL (4), 257-269.

Pajusalu, Renate, Karl Pajusalu 2010. Konditsionaal relatiivlauses. - ESUKA JEFUL 1 (2), 243-254.

Palmer, Frank Robert 2001. Mood and Modality. Cambridge: Cambridge University Press.

Pataki, Pál 1984. A francia subjonctif és a magyar kötőmód. - Általános Nyelvészeti Tanulmányok XV. Budapest: Akadémiai Kiadó, 207-218.

Pomozi, Péter 1991. Néhány gondolat a magyar "konjuktívusz"-ról. - Zoltán Éder (Szerk.). Dolgozatok a magyar mint idegen nyelv és a hungarológia köréből 26. Budapest.

Prileszky, Csilla 1974. A felszólító módú mellékmondat néhány kérdéséről. - Imre Samu, István Szathmári, László Szüt (Szerk.). Jelentéstan és stilisztika. A magyar nyelvészek II. Nemzetközi kongresszusának előadásai. NytudÉrt. 83. Budapest: Akadémiai Kiadó, 473-475.

Pusztay, János 1998. A magyar imperatívuszi állítmányú mellékmondatok (IÁM) megfelelései az észtben. - Folia Estonica VI. Észt-magyar összevetés II. Szombathely: Berzsenyi Daniel Tanarkepzö Föiskola, 19-34.

Rätsep, Huno 1971. Kas kaudne kõneviis on kõneviis? Verbivormide situatsioonianalüüsi. - Keel ja Struktuur 5. Töid strukturaalse ja matemaatilise lingvistika alalt. Tartu: Tartu Ülikool, 45-69. 
Rüütmaa, Tiina 2007. Ungari ja eesti kõneviisid kõrvallauses. - János Pusztay (Szerk.). Folia Estonica XI. Szombathely: Berzsenyi Daniel Tanarkepzö Föiskola, 88-100.

Rüütmaa, Tiina 2010. Imperatiiv ja konditsionaal ungari ja võrdlevalt eesti kõrvallauses. - Lähivõrdlusi. Lähivertailuja 20, 240-263. http://dx.doi. org/10.5128/LV20.08

Sepper, Maria-Maren 2007. Indirectal in literary Estonian. - Trames 11 (3), 299323.

Thieroff, Rolf 2010. Moods, moods, moods. - Björn Rothstein, Rolf Thieroff (Eds.). Mood in the Languages of Europe. Studies in Language Companion Series 120. Amsterdam: John Benjamins,1-29.

Tompa, József 1972. Kleine Ungarische Grammatik. Budapest: Akadémiai Kiadó.

Toomet, Piret 2000. Mõnest kaudsuse väljendamise võimalusest tänapäeva eesti keeles. - Keel ja Kirjandus 4, 251-259.

Tóth, Enikő 2005. Az alárendelt mellékmondatbeli kötő- illetve felszólító módról. - Balázs Sinkovics (Szerk.). Nyelvész-doktorandusok dolgozatai. LingDok 4. Szegedi Tudományegyetem Nyelvtudományi Doktori Iskola.

Tóth, Enikő 2008. Mood Choice in Complement Clauses. A Semantic Approach with Special Reference to Hungarian. Metalinguistica 21. Frankfurt am Main, Berlin, Bern, Bruxelles, New York, Oxford, Wien: Peter Lang.

\section{Tiina Rüütmaa}

Tallinna Ülikooli eesti keele ja kirjanduse instituut

Narva mnt 29

10120 Tallinn, Estonia

rtiina@tlu.ee 


\title{
Moods in the Estonian subordinate clause and their equivalents in Hungarian
}

\author{
TIINA RÜÜTMAA \\ Tallinn University, University of Tartu
}

The main objective of the research is to map the functional equivalents in the Estonian and Hungarian mood systems. Examining the mood system in subordinate clauses also provides insight into those aspects of mood choice that occur only in the subordinate clause. The study also examines the Estonian subordinate clause containing the $d a$-infinitive predicate as a frequent subordinate clause type.

The differences in the mood systems of Estonian and Hungarian are partly due to differences in grammatical tradition (i.e. the lack of jussive in Hungarian) and partly to differences in the two language systems (several uncommon functions of the Estonian conditional and Hungarian imperative, the lack of quotative in Hungarian, etc.).

After a survey of the treatment of moods in Estonian and Hungarian some examples of subordinate clauses taken from Estonian texts are compared with their Hungarian equivalents. The equivalent of the Estonian indicative in the subordinate clause is usually indicative in Hungarian as well, but the indicative predicate of the Estonian relative clause may also be embedded as an attribute in an independent clause in Hungarian. The widest range of different equivalents is associated with the Estonian conditional in the subordinate clause: most frequently conditional (usually in conditional and object clauses) or imperative (mostly in clauses where the Estonian conditional has conjunctive-like functions, i.e. in purpose and object clauses), sometimes indicative. The Hungarian equivalent of a $d a$-infinitive predicate in the Estonian subordinate clause most commonly occurs in the imperative (in purpose clauses, sometimes also in object clauses or governmental adverbal clauses), less frequently indicative (in conditional clauses, and in some subject, object and relative clauses) or con- 
ditional. There were insufficient Estonian subordinate clauses with quotative or imperative predicates to permit any conclusions to be drawn.

Keywords: contrastive linguistics; indicative; imperatiive; conditional; jussive; quotative; conjunctive; $d a$-infinitive; Estonian; Hungarian 